and the parts of the genotype : the genes of a nucleus must be related in action, and the characters must be related in development." Without such a correspondence genes cannot be either "completely independent" or " essentially additive".

Williams' attempt to partition the genotype in order to justify his arbitrary separation of genetics into genetics and somatics has led to an unnecessary attack on gene interaction which only confuses the whole problem of hybrid vigour.

\title{
REFERENCES
}

GRafius, J. E. 1959. Heterosis in barley. Agron. 7., 5I, 55 I.

MATHER, K. 1949. Biometrical Genetics. Methuen, London.

williams, w. 1959. Heterosis and the genetics of complex characters. Nature, 184,527 .

\section{HETEROSIS AND THE GENETICS OF COMPLEX CHARACTERS}

\author{
WATKIN WILLIAMS \\ John Innes Institute, Bayfordbury
}

Received 3.x.6o

Dr Hayman in his comments (Hayman, I960) on my discussion of heterosis in tomato crosses (Williams, I959) is troubled primarily by the distinction that $\mathrm{I}$ attempted to draw between somatic and genetic interaction. He will apparently tolerate none other than the genetics-at-all-cost interpretation in the understanding of the biology of complex characters (para. 8) and, in taking his stand, he finds it necessary to claim exclusive rights for his own explanations of such open subjects as gene action and the absolute properties of genetic systems. Purely dialectical arguments of the kind which Hayman develops can no longer be expected to contribute materially to the advance of scientific knowledge, and, if his comments had been less obviously personal, I would have considered any form of reply as a somewhat idle exercise. In the circumstances I wish merely to point out the basic differences between Hayman's point of view and my own in our effort to provide an explanation of heterosis.

Dr Hayman appears to fail to dispute that my observations on the essential role of somatic interaction might prove more useful as a basis of understanding heterosis. He however decides to dismiss the criterion of usefulness as a measure of merit in one phrase, and elects to submerge in an inconclusive semantic discussion what is surely a most important consideration when one is attempting to rationalise such a highly intractable subject. In so doing he has tried to create the impression that ideas on heterosis which invoke considerations of somatic interaction are not only amusingly simple in theory but also useless in practice. The difficulties that have led to this curious tangle appear to stem from Dr Hayman's eagerness to include under the term gene interaction all the interacting processes of development irrespective of whether or not there is any logical reason for suspecting interactions between genes or gene products at the level of the cell. On this view gene interaction is a condition which can be inferred from analyses of weights and measurements of phenotypes 
with little or no reference to underlying biological systems. A simple example may be cited to expose the dangers inherent in this approach. One may, for instance, contemplate a complex character such as the ability to write as an interaction between muscular control and brain power, and, according to Dr Hayman's inclinations, may devise a method of analysis to suggest gene interaction as the exclusive basis of the Seven Pillars of Wisdom. This is one way of viewing all complex characters, particularly heterosis, but it is hardly a rational approach and in practice it has not proved to be notably helpful. It has its origin in the understandable desire to formalise all phenotypic manifestations in terms of Mendelian genes. But, in describing integrated characters that are at the remote extremes of gene action, over-simplified gene models would seem to have little justification, and terms such as gene interaction need very careful usage. The use of such a term in the way Dr Hayman would have it used denudes it of all precision, and invites such universality of application and glibness in discussion that the very existence of the term becomes a positive drag on further inquiry.

The data which I reported on the tomato can be described very adequately and simply by consideration of somatic interaction superimposed on the genetic system. Hayman's appeal to the logarithmic scale seemed to me to offer no guidance. One should not be deluded into a false reality merely by describing one's data in a basically different language, which is what a set of log tables is calculated to do in this connexion. If, as seems likely, similar models are found satisfactory for other characters and in other organisms (Leng, r954), an approach to the study of heterosis is immediately simplified and many of the practical problems connected with the selection of parents and prediction of breeding performance can be approached by straightforward observations on the phenotype. Such a development could hardly fail to be an improvement on current concepts invoking an unknown number of genes which can neither be located on the chromosomes nor identified by any specific action and which are created to fit characters that are only inferred and arbitrarily allocated.

Finally, may I draw attention to Dr Hayman's charge of confusion in my sentence, "Phenotypic characters may be multiplicative and may consequently show a mutually dependent relationship while the gene system is strictly additive and its units strictly independent in function." The genetic system I outlined in the model was additive. Allelic interaction was absent in the determination of the level of the components in many of the hybrids, and non-allelic interaction was rejected as unnecessary for the interpretation of heterosis in the compound character-fruit yield. Multiplicative relationships between the components was suggested to occur at the somatic level, and it is this attempt to make a distinction between events at the genic level and those at the somatic level which Dr Hayman refuses to grasp.

\section{REFERENCES}

HAYMAN, B. I. I960. Heterosis and quantitative inheritance. Heredity, 15, 324-327. LENG, E. 1954. Effects of heterosis on the major components of grain yield in corn. Agron. 7., 46, 502,

williams, w. 1959. Heterosis and the genetics of complex characters. Nature, Lond., $184,527$. 